\title{
Legislative Comprehensiveness - an Assessment of two Tanzanian Provisions
}

\author{
By Zebron Steven Gondwe
}

In recent years the author of this paper has become progressively interested in the capability of various pieces of local land legislation to cater for the needs for which they were ostensibly made. Of particular interest to the author has been the examination of specific legal provisions, namely, sections, clauses, paragraphs, articles and the like. In the short period since this interest was aroused, the author has been able to identify two phenomena - this by no means being comprehensive - and these are as follows:

1. A provision which does not exhaustively cater for a situation for which it was made (hereinafter, "Phenomena One"),

2. A provision which exhaustively caters for the situation envisaged but its literary presentation is so complex that the import can escape all, but microscopic, scrutiny (hereinafter, "Phenomena Two").

As far as Phenomena One is concerned, section 14 (b) of the Land Ordinance ${ }^{1}$ is the case in point. This provision states thus:

14. Every certificate of occupancy shall be deemed to contain provisions to the following effect:

(a) ...

(b) that the occupier binds himself to pay to the President on behalf of the previous occupier, if any, the amount found to be payable in respect of any unexhausted improvements existing on the land at the date of his entering into occupation and that this condition shall not be discharged by the occupier making payment of the whole or any part of such amount direct to the previous occupier.

The spirit behind this provision can be grasped only after one is acquainted with the key terms in it. A certificate of occupancy is a document evidencing the grant of a Right of Occupancy. ${ }^{2}$ A Right of Occupancy is, generally, the title to the use and occupation of land $;^{3}$ conversely, it is the right to the use and occupation of land. The person who holds

1 The Land Ordinance, Cap 113.

Originally, the Land Tenure Ordinance 1923, No. 23 of 1923. The Land Ordinance is the principal land legislation in Tanzania but, notably, most of its provisions are concerned with statutory tenure.

2 See subsections (1) and (2) of section 9 of the Land Ordinance, op. cit. Also note 26 infra.

3 Section 2 of the Land Ordinance. The full definition is as follows: -

"right of occupancy" means the title to the use and occupation of land and includes the title of a native or of a native community lawfully using of occupying land in accordance with native law and custom; The definition covers both statutory and customary titles. Statutory Rights of Occupancy are granted under sections 6 and 12 of the Land Ordinance. 
such a right is known as the "occupier". ${ }^{4}$ The permanent improvements that such an occupier effects on the land the subject of the Right of Occupancy are termed "unexhausted improvement $"$. ${ }^{5}$

Coming back to the spirit of the provision; in the event of revocation, ${ }^{6}$ expiry ${ }^{7}$ or surrender ${ }^{8}$ of a Right of Occupancy, the incoming occupier is obliged to compensate the outgoing occupier for any unexhausted improvements that the latter may have effected on the land. Compensation, as a principle, has won acclaim in both administrative ${ }^{9}$ and political ${ }^{10}$ circles for a long time, thus its inclusion in the Land Ordinance is in no way unique. But one of the key features of this provision, a feature which is absent from all other legislation which prescribe for compensation, is that the compensation payable shall be received by the President and not directly by the person entitled thereto. The President would then relay the amount so received to such a person, viz. the outgoing occupier. Some of the justification for this course of action is found in the Land Ordinance itself ". ${ }^{11}$

In this fashion the provision, a searlier noted, facilitates the payment of compensation by the incoming occupier to the outgoing occupier. One need not look far, though, to see that the successful operation of the provision hinges on one major assumption. It assumes a smooth transition from one occupancy to another. Of course much would turn

For a more elaborate discussion of the concept see R. W. James, Land Tenure and Policy in Tanzania (Dar es

Salaam: East African Literature Bureau, 1971) Chapters 4 and 5.

4 Section 2 of the Land Ordinance. The full definition is as thus: -

noccupier" means the holder of a right of occupancy and includes a native or a native community lawfully using or occupying land in accordance with native law and custom;

5 Section 2 of the Land Ordinance. Following is the full definition: -

"unexhausted improvement " means anything or/any quality permanently attached to the land directly resulting from the expenditure of capital or labour by an occupier or any person acting on his behalf and increasing the productive capacity the utility or the amenity thereof, but does not include the result of ordinary cultivation other than standing crops or growing produce.

There are two parallels, and, one contrast, between the concept unexhausted improvement and the common law doctrine of "fixture". They are both affixed to land and they both have the element of permanency. The contrast is: while the former are invariably affixed to public land, the latter are ideally attached to freeholds. For a general insight into the concept "public land", see sections 3 and 4 of the Land Ordinance.

6 Sections 10, 14C and 14D of the Land Ordinance.

7 By effluxion of time. A Right of Occupancy cannot be granted for a term exceeding ninety-nine (99) years see subsection (2) of section 6 of the Land Ordinance.

8 Save for section 16, quoted in extenso in the text of this paper, the Land Ordinance makes no provision for the incident of surrender. But the Land Office (see note 16 infra) would normally accept a voluntary surrender from an occupier where the occupier feels he is not capable of complying with the development conditions attached to the grant, or where he considers the land unsuitable for the purpose for which it was required.

9 See for example, Para. 12 and Appendix 1 of Government Circular No. 4 of 1953.

10 One example of this is in J. K. Nyerere, "The National Property", Freedom and Unity (Dar es Salaam: Oxford University Press, 1974), p. 54. At that page Nyerere contends that: -

By clearing that ground I have actually added to its value and have enabled it to be used to satisfy a human need. Whoever then takes this piece of ground must pay me for adding value to it through clearing it by my own labour.

11 Section 14B of the Land Ordinance. The section allows the President to pay of unpaid mortgages from the compensation due to the outgoing occupier before relaying the balance to such occupier. 
on the availability of a ready incoming occupier. ${ }^{12}$ Conversely, that immediately after the revocation, expiry or surrender of a Right of Occupancy there should be someone ready to take up the occupancy of the land in question.

Two questions fall for consideration concerning the foregoing observation. These are as follows:

1. How will the outgoing occupier be assured of his compensation where there is no ready incoming occupier?

2. How long does the outgoing occupier have to wait before he receives such compensation?

For some cases of surrenders of Rights of Occupancy, a recent amendment ${ }^{13}$ to the Land Ordinance has made the position much more predictable. The relevant provision is sevtion 16 of the Land Ordinance and it states as follows:

16. Should the rental demanded by the President from the occupier be raised on revision, the occupier may surrender his right, and shall in the case be entitled to compensation from the President to the value at the date of surrender of his unexhausted improvements. Such compensation shall be payable when the surrendered right are (sic) disposed of. Provided that in any event it shall be payable within two years of such surrender.

Clearly, this provision is addressed to surrenders of Rights of Occupancy which are prompted by revisions of land rent. ${ }^{14}$ Where an occupier cannot afford the revised rent, he is allowed to surrender his right whereupon he will be entitled to compensation from the President - and not from the incoming occupier. This compensation is not paid until the land in question is granted to another occupier or within two years of the surrender, whichever is the earlier.

In such situations, therefore, though there may be no ready incoming ocupier, the previous occupier is assured of compensation from the President. This compensation has to be paid within a period of two years.

Evidently, as far as the question of the payment of compensation to previous occupiers is concerned, section 16 of the Land Ordinance offers a greater measure of predictability than section 14 (b) of the same Ordinance.

Admittedly, surrenders of Rights of Occupancy which are prompted by other reasons ${ }^{15}$ are not covered by the said section 16 of the Land Ordinance, and they, therefore, cannot benefit thereunder. In actual fact, where there is a surrender of a Right of Occupancy for reasons not connected with rent revision the person so surrendering has only section

12 Assuming that such incoming occupiers have the financial capability to pay the requisite compensation.

13 Introduced by section 53 of the Urban Authorities (Rating) Act, 1983, No. 2 of 1983.

This, however, is not the first time that the Land Ordinance carries such a provision - see James, Land Tenure and Policy, op.cit., at page 126.

14 Section 7 of the Land Ordinance makes provision for the incident of rent generally. It is subsection (4) of that section, however, which specifically caters for the matter of rent revision.

15 For example, failure to comply with development conditions or unsuitability for the purpose for which the land is required. See note 8 , supra. 
14 (b) of the Land Ordinance to rely on for compensation. Here is where the inadequacy of the said provision may crop up again: there is no guarantee to compensation where there is no ready incoming occupier and there is no pre-determined period within which the compensation has to be paid.

The positions taken by the Land Office ${ }^{16}$ on the legal aspect, on the one hand, and the practical aspect, on the other, are quite interesting and they merit some consideration. On the former, the Land Office ${ }^{17}$ was candid enough to admit that the legislation on land was silent on the two problems - identified above - which afflict section 14 (b) of the Land Ordinance.

However, it is the views of the Land Office on the practical aspect of the matter which merit closer examination. Such views fall into two broad categories. These are as follows:

(a) Real-life solutions, and

(b) Speculative solutions.

In connection with real-life solutions the Land Office made three important observations. For the sake of expediency these observations are enumerated thus: -

(i) That a Right of Occupancy is, normally, not revoked save where an incoming occupier has already been identified. Conversely, that a Right of Occupancy is only revoked after another person has shown willingness to take up the land, and, or, buildings in question.

(ii) That where a permanent structure ${ }^{18}$ stands on land the subject of a revoked Right of Occupancy, the National Housing Corporation ${ }^{19}$ may be asked to take over the ownership of the said structure.

(iii) That if there are permanent crops $^{20}$ on the land the subject of a revoked Right of

16 In this paper the term "land of fice" means the headquarthers of the Ministry of Lands, Housing and Urban Development, Regional Land Development Offices and District Land Development Offices.

17 Courtesy of S. D. Mtetewaunga, Principal Land Officer and, currently, Acting Director for Land Development Services at the Land Office headquarters, and G. N. C. Chagula, a Senior Land Officer in the same office.

I express my profound gratitude for the cooperation.

18 For purposes of this discussion the relevant provision is special condition 2 (i) of the Certificate of Occupancy currently being issued by the Land Office. See also note 26 infra.

19 Established by the National Housing Corporation Act, 1962, No. 45 of 1962. By section 4 of the Act the business of the Corporation shall be to provide and to facilitate the provision of houses and other buildings in the country. The Bill of the Act, L.G.C. 139/04, was published on 31st May, 1962. One of the paragraphs in the Objects and Reason states thus: -

The Bill is designed to establish a National Housing Corporation the purpose of which will be to facilitate the provision of housing and other buildings in Tanganyika by the giving of financial assistance and by the development of housing schemes.

20 The First Schedule to the Land Regulations, 1948, (see also note 30, infra) lists down items that could be regarded as permanent improvements. With regard to crops, however, the list is not very illustrative: the only relevant statement being: "Planting trees or live hedges."

R. W. James and G. M. Fimbo, in: Customary Land Law of Tanzania - A Sourcebook (Dar es Salaam: East African Literature Bureau, 1973), p. 296, give coffee, coconuts, bananas and sisal as examples of permanent crops. 
Occupancy the relevant local authority ${ }^{21}$ may be asked to take up the land in question.

It is evident that the last two observations are merely elaborative of the first one. In other words, the first observation constitutes the major premise as far as the three real-life solutions are concerned. Doubtlessly, it would also seem to be the most credible of the three for the simple reason that in this way the availability of a ready incoming occupier would be assured. ${ }^{22}$ Inherent in this course of action, however, is another problem: revocation may be delayed due to the unavailability of an incoming occupier! In other words, a perfectly justifiable revocation may have to be deferred for lack of an incoming occupier. Naturally, this would put the President ${ }^{23}$ at a disadvantage.

Nothing much can be said on the other two courses of action apart from the fact that their success really turns on the disposition of the relevant institutions towards the buildings or crops in question. The said institutions cannot, of course, be forced to accept everything which might be in the offering. There is simply no legal basis for such a thing. It remains, therefore, that such institutions have a perfect right to accept or decline whatever may be offered to them at any point. Where the offer is declined, the problem being discussed here would retain its significance.

Without more, it is abundantly clear that these three courses of action do not constitute what could be regarded as fool-proof solutions. They are, at best, mere tools of convenience. It appears, however, that the Land Office has met with considerable success in this regard. In fact a senior official in that office remarked that with such an arrangement he could not envisage a situation where a Right of Occupancy could be revoked without a ready incoming occupier.

It is, nevertheless, recommended that comprehensive legislation on the point would constitute a more dependable solution than the ones discussed above.

Less comfort can be derived from what have here been tabbed "speculative solutions." These are, basically, two:

(i) That the occupier could pull down any structure standing on the land subject of the revoked Right of Occupancy and hand the vacant ground back to the President while removing any material that he can take away e. g., doors, windows, bricks, roofing elements etc. ${ }^{24}$

(ii) That, to expedite the process of obtaining a new occupier for a revoked Right of Occupancy, either the President or the previous occupier could advertise in the

21 For examples of local authorities see section 2 of the Town and Country Planning Ordinance, Cap. 378.

22 It is assumed that such an occupier would be able to effect the prompt payment of compensation. See also note 12 , supra, and the related discussion in the text.

23 Section 10 of the Land Ordinance is the provision which empowers the President to revoke a statutory Right of Occupancy. It is noteworthy that by Regulation 2 of the Land Regulations, 1948, the term "president" includes any person exercising any powers or duties under the Land Ordinance which have been lawfully delegated to him by the President.

24 Apparently the of ficial had in mind Rights of Occupancy for building purposes. These are common in urban areas. 
news media ${ }^{25}$ that the material land is available for occupation by any interested party.

The first proposition is, simply, an alarming prospect. If such a course of action were to be adopted it would clearly militate against the true intent and meaning of the Land Ordinance. An examination of the said Ordinance and other related provisions is quite illustrative in this regard!

Subsection (5) of section 7 of the Land Ordinance provides as follows:

(5) A right of occupancy may be granted subject to the terms of any contract made between the President and the grantee which are not inconsistent with the provisions of this Ordinance.

The terms of the said contract, when executed, are normally contained in the Certificate of Occupancy ${ }^{26}$ - but in such certificate the terms are called "special conditions." Condition 2 thereof states as follows:

2. The Occupier shall:

(i) Erect on the land buildings (hereinafter called "the buildings") in permanent materials designed for use in accordance with the conditions of the Right and which comform to the building line (if any) decided by... (hereinafter called "the Authority")

(v) At all times during the term after the ... day of . ., $19 \ldots$, have on the land buildings as approved by the Authority and maintain them in good order and repair to the satisfaction of the Commissioner for Lands (hereinafter called "the Commissioner" $)^{27}$

Of course it is after the lapse of the Right, and assuming that it is not renewed, that section 14 (b) of the Land Ordinance, the theme of the discussion, would become operative. The gist of the provisions cited above, therefore, is not only that the land should be developed, but also that such developments should be properly maintained. The need to retain such developments should be properly maintained. The need to retain such developments on the land is clearly one of the reasons that prompted the enactment of section 14 (b) of the Land Ordinance. Where a Right of Occupancy is not renewed, on expiry, the occupier would get the value of his developments while leaving such developments intact. It defeats the logic of these provisions, therefore, to suggest that an occupier should pull down his developments upon the revocation of his Right of Occupancy. The proper thing to do, it would seem, is to take measures that would ensure the prompt payment of compensation to the previous occupier.

25 The mediums normally used in this regard are the local newspapers, for example, the Daily News, the Sunday News, "Uhuru" and "Mzalendo".

26 A Certificate of Occupancy is issued under section 9 of the Land Ordinance. In the land office it is also known as Land Form 32.

27 Now known as the Director for Land Development Services. It is amazing that the Certificate has not been amended to reflect this change! This was one of the changes recommended by the McKinsey Report of 1972 on the decentralization of government business. The government adopted the recommendation. 
The second speculative solution depends, for its success, on advertising outlets. In any case it appears that emphasis in such an advertisement would, inter alia, be on the description and value ${ }^{28}$ of the property. Again the success of this method would turn much on the type of response that it can elicit. In sum, the response could be either positive or negative thus underscoring the theme of this exposition: that the position regarding compensation should be made more comprehensive.

The discussion in the preceding pages has identified the flaws in both the real-life and speculative solutions. In the final analysis it all boils down to this: neither the law nor the practice offer a full-proof mechanism that could ensure the availability of a ready incoming occupier. As a consequence, the previous occupier may have to wait for any length of time for his compensation in the event of the non-availability of a ready incoming occupier.

Admittedly, the problem may seem to be more imagined than real. In fact one official remarked that it would not be easy to get a situation where a Right of Occupancy is revoked before a new occupier is obtained. However, it equally cannot be denied that the best legislative provision is that which exhaustively caters for the situation it was intended to cover. Indeed, when querried on the course of action that the Land Office would adopt where both the real-life and speculative solutions failed to work, the same official remarked:

I don't know what would happen for we always act in accordance with the law, and in this case the law is silent.

The inevitable question is: What solution does the author have in mind?

The solution being recommended is neither spectacular nor exactly original. In point of fact it is more of an extension of the principle contained in section 16 of the Land Ordinance. Section 14 (b) of the Land Ordinance should carry a proviso couched as follows:

Provided that in any event such amount shall be payable within one year of the determination of the previous occupancy by the occupier, if any and where there is none by the President. ${ }^{29}$

In this fashion the outgoing occupier would be assured of his compensation from the President in the event of the non-availability of an incoming occupier. Moreover, the outgoing occupier would have to wait for a readily ascertainable period of one year before receiving his compensation. Where the President pays the compensation provision for recouping the same from a subsequent occupier could be made in one of the special conditions in the Certificate of Occupancy.

That has to be so on the strength of clause (b) of Regulation 8 of the Land Regulations, 1948. That clause states as follows: -

the amount of compensation which shall be payable shall be the amount that would fairly represent the value of the improvements to the incoming occupier as determined by the President, whose decision shall be final.

29 The period of one year is considered to be appropriate because while it allows the Land Office enough time to finalize the administrative procedure involved, it is not likely to allow significant variations in values. 
Phenomena Two concerns a provision which comprehensively covers the situation envisaged but, the ascertainment of its import literally requires microspic scrutiny. The provision in question is Regulation 3 of the Land Regulations of $1948 .{ }^{30}$ This Regulation states as follows:

3 (1) A disposition of a right of occupancy shall not be operative unless it is in writing and unless and until it is approved by the President.

(2) In this regulation "Right of Occupancy" means a Right of Occupancy granted under section 6 or section 12 of the Land Ordinance.

(3) In this regulation "disposition" means

(a) $\ldots$

(b) a mortgage other than -

(i) $\ldots$

(ii) a mortage which by law is only effectual if registered in the Register of Documents or the Land Register.

Duration-wise, Rights of Occupancy fall under two broad categories: short term and long term. ${ }^{31}$ Both types may be mortgaged. The position regarding mortgages of long term Rights of Occupancy is, relatively, clearer than that pertaining to short term Rights of Occupancy. Generally, not only the title but also all transactions, mortgages included, involving long-term Rights of Occupancy have to be registered in the Land Register ${ }^{32}$ established under the Land Registration Ordinance. ${ }^{33}$ In as much as the validity of a mortgage of a long term Right of Occupancy turns on its registration in the Land Register, ${ }^{34}$ such a transaction would, therefore, not require approval under the Land Regulations of $1948 .^{35}$

The position regarding mortgages of short term Rights of Occupancy is the one which really presents problems. ${ }^{36}$ Do such transactions require Presidential approval or not? This question can only be answered after the following inter-connected questions are disposed of. These are:

(i) Is a mortgage of a short-term right of occupancy a "disposition" within the meaning of the Land Regulations of 1948 ?

30 The Land Regulations, 1948, G.N. 232 of 1948. These Regulations were made under subsection (ii) of section 23 of the Land Ordinance. They are read as one with the said Ordinance.

31 For a more elaborate treatment of the question of the classification of Rights of Occupancy see James, Land Tenure and Policy, op.cit, pp. 114-116.

32 The register is set up under section 3 of the Land Registration Ordinance, Cap. 334. Subsection (1) of section 2 of the same Ordinance provides thus: -

"land register" means the land register to be maintained by the Registrar under the provisions of subsection (2) of section 3 .

33 The relevant provisions in this connection are sections 2, 27 and 41 of the Land Registration Ordinance, Cap. 334. In section 2, the material part is the definition of the term "disposition".

34 Non registration would result in the creation of an equitable mortgage. A creation by omission! See also James, Land Tenure and Policy, op.cit., pp. 310-311.

35 But where the mortgage is executed by a native in favour of a non-native, the transaction must be approved under section 11 of the Land (Law of Property and Conveyancing) Ordinance, Cap. 114.

36 I am not ashamed to admit that it took me no less than one week to hammer-out the correct legal position. 
(ii) Does the validity of a mortgage of a short-term Right of Occupancy depend on its registration in the Register of Documents ${ }^{37}$ or the Land Register?

It is only dispositions of registered estates which have to be inscribed in the Land Register, ${ }^{38}$ such estates actually being land the subject of long term Rights of Occupancy. ${ }^{39}$ Conversely, the validity of a mortgage of a short term Right of Occupancy does not depend on its inscription in the Land Register.

Another issue calling for determination is whether such mortgages have to be registered in the Register of Documents, a Register set up under the Registration of Documents Ordinance. ${ }^{40}$ The relevant provisions in the said Ordinance are sections 8 and 9 , and these, inter alia, provide as follows:

8 (1) The registration of the following documents if executed or made after the commencement of this Ordinance is compulsory -

(a) non-testamentary documents including decrees of any court and awards, which pupport or operate to create, confer, declare, limit, assign, transfer or extinguish any right, title, or interest, whether vested or contingent, to, in, or over land;

(b) $\ldots$. .

(2) Nothing in clauses (a) and (b) of subsection (1) applies to -

(h) any document evidencing the grant of a lease, or a right of occupancy, for a term of five years or less, or any document if the only interest in land dealt with thereby is derived from such grant, or is an interest in standing trees or timber or growing crops or grass, where such trees, timber or growing crops or grass are to be removed within one year from the date of the document;

9. No document of which the registration is compulsory shall be effectual to pass any land or any interest therein or render such land liable as security for the payment of money or be received as evidence of any dealing affecting such land unless and until it has been registered.

The short of it is that non-testamentary documents which support or operate to create any interest over land can only be effectual, in that behalf, after their inscription in the Register of Documents. As to whether mortgages of short term Rights of Occupancy are caught by this requirement one has to examine clause (h) of section 8 (2) closely. That clause qualifies the general principle carried in subsection (1) of section 8 and section 9 . The qualifications that concern us are two in number, namely:

(i) Any document evidencing the grant of a Right of Occupancy for a term of five years of less.

(ii) Any document if the only interest in land dealt with thereby is derived from such grant.

37 The Register is established by clause (a) of section 4 of the Registration of Documents Ordinance, Cap. 117.

38 Section 2 of the Land Registration Ordinance, Cap. 334.

39 Section 27 of the Land Registration Ordinance, Cap. 334.

40 The Ordinance commenced operation on 1st January, 1924. 
A mortgage of a short term Right of Occupancy, therefore, is not subject to compulsory registration in the Register of Documents because the only interest in land dealt with thereby is derived from a grant of a Right of Occupancy for a term of five years! ${ }^{41}$ Reverting to the two inter-connected questions, these can now be answered thus:

(i) The validity of a mortgage of a short term Right of Occupancy does not turn on its registraton either in the Register of Documents or the Land Register;

(ii) A mortgage of a short term Right of Occupancy is, therefore, a disposition within the meaning of the Land Regulations of 1948.

Consequently, a mortgage of a short term Right of Occupancy definitely needs Presidential approval under Regulation 3 of the Land Regulations of 1948 before it can become operative. ${ }^{42}$ But consider the effort involved in identifying the correct legal position! Would it be possible for a beginner in legal studies to sort his way out of this legislative maze ${ }^{43}$ Indeed the author and his class ${ }^{44}$ spent a good one week trying to piece together this legal quiz, fortunately the effort was finally crowned with success. ${ }^{45}$ The difficulty, primarily, seems to lie in the fact that the material parts of the correct legal position are scattered in a number of provisions contained in different legislative enactments. ${ }^{46}$ One then, literally, has to tear the said provisions to shreds, pick up the right threads and weave the correct legal fabric! It would definitely be more helpful to everybody concerned if this legal position were expressed in a more straight-forward manner.

The importance of the requirement for governmental approval to transactions involving land need not be over-stressed; ${ }^{47}$ it is desirable, therefore, that the related legal position should be readily ascertainable. No attempt shall be made her to recommend a solution. In preference, a challenge is thrown to the Parliamentary Draftsman ${ }^{48}$ to come up with the appropriate phraseology and literary presentation for this important principle as it relates to mortgages.

41 But the mortgage may be registered under the optional registration provision, viz, section 11 of the Registration of Documents Ordinance, Cap. 117.

See also, James, Land Tenure and Policy, op.cit., p. 114.

42 Of course it also has to be in writing - see clause (1) of Regulation 3 of the Land Regulations of 1948 in the text. Moreover, if the mortgage is executed by a native in favour of a non-native, it will require additional approval under section 11 of the Land (Law of Property and Conveyancing) Ordinance, Cap. 114. cf., note 35 and the related discussion in the text.

43 I would not be surprised if qualified lawyers were to experience the same difficulty.

44 Second-year LL.B., degree course, class of 1983/84.

45 Thanks mostly to one of my students, f. B. Luoga. He was the first to locate the all important hint, namely, A. B. Lyall, "Consent to Disposition of Land in Tanzania: Socialism or the Extension of Private Property", Eastern Africa Law Review, Vol. 4, No. 3 (Dec. 1971) p. 247. See also note 39 at the same page.

46 The enactments are: -

(i) The Land Regulations of 1948

(ii) The Land Registration Ordinance, Cap. 334

(iii) The Registration of Documents Ordinance, Cap. 117.

47 James, in Land Tenure and Policy, op.cit., devotes a whole chapter, Chapter 8, to the discussion of this principle.

48 And, perhaps, the recently established Law Review Commission. 
The paper has exposed the substantive defects, on the one hand, and the formal defects, on the other, of two local provisions. These two phenomena may only be representative of the difficulties that our legislation is probably fraught with. As the saying goes: there is no point in crying over spilt milk. A call is instead made to everybody who is involved in the legislative process that now is the time to turn out comprehensive and unsophisticated inactments.

\section{Glaubwürdige Vergangenheitsbewältigung heißt auch: \\ SOLIDARITÄT MIT SINTI UND ROMA}

\section{Bürgerrechtsarbeit ist immer noch notwendig:}

\section{gegen}

Polizei- und Behördenwillkür, einseitige und diffamierende Presseberichterstattung,

für

Wiedergutmachung, Rentenansprüche, menschenwürdige Wohnungen, angemessene Ausbildung, ungehindertes Reisen, Legalisierung staaten- und heimatloser Roma in der Bundesrepublik und Westeuropa, Anerkennung und Respektierung kultureller Traditionen, Unterstützung der Sinti- und Roma-Verbände.

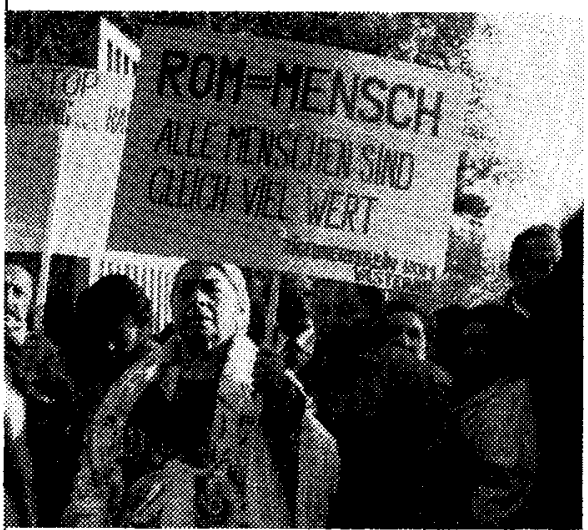

Gesellschaft für bedrohte Völker gemeinnütziger Verein

Postfach 2024, 3400 Göttingen

Tel: 0551-55822/23

Postscheck Hamburg 297793-207
Unterstützen Sie diese Bürgerrechtsarbeit der „Gesellschaft für bedrohte Völker e.V.“ über das Sonderkonto 7400 Postscheck Hamburg, Stichwort >Sinti und Romar.

$\bigcirc$ Hiermit bestelle ich umf assendes Informationsmaterial zur Situation der Sinti und Roma

(Unkostenbeitrag DM 38,-)

3:Bücher, 6 Sonderausgaben von Zeitschriften

Zur 600jährigen Geschichte der Verfolgung - Standardwerk zum NS-Völkermord-Situation und Bürgerrechtsbewegung der Sinti in Deutschland und Roma in Europa - Kultur und Musik Vertreibung jugoslawischer Roma in Westeuropa - Sondererfassung im BKA - u.a. 


\section{International Aspects of Social Security in French-Speaking Countries of the Sahara}

\section{By Otto Kaufmann}

The scanty social security legislation introduced during the colonial period by French and Belgian colonial administrations was applied in all colonial territories. Therefore, problems concerning social security of migrant workers did not exist.

After independence, the new African countries each adopted national social security legislation. Despite the common French or Belgian influence, differences appeared between the different national social security systems. The reasons for these differences are various, but their consequence is the necessity to take measures in favour of African migrant workers.

Indeed, in the absence of coordination or harmonization of national social security legislations, migrant workers may be disadvantaged. Measures in the field of harmonization of social security legislation may consist in ratifying ILO conventions, especially the convention no. 102. But harmonization, for several reasons, has to be completed by coordination measures. The African countries concerned could apply the ILO's coordination principles and standards. But one can observe a predominance of multilateral solutions within African subregional organizations. The existing multilateral instruments are the social security convention of the Common African and Mauritian Organization (OCAM) and the conventions of the Economic Community of the Countries of the Great Lakes (CEPGL). The two conventions comprise the principle of national treatment, rules for the determination of the applicable law, the maintenance of acquired rights and the maintenance of rights in course of acquisition. There are still many obstacles to overcome, but this manner of coordination seems to be the best to guarantee the social rights of the migrants. That is why other African organizations are also engaged in negotiations about social security.

\section{Legislative Comprehensiveness - An Assessment of Two Tanzanian Provisions}

\section{By Zebron Steven Gondwe}

It is now probably settled that law is an obligatory rule of conduct, it enjoins or prohibits certain action in a community. However, full utility of law is possible where it comprehensively provides for the situation sought to be governed. The article, citing two Tanzanian legal provisions as illustrations, shows how legal comprehensiveness may be impaired. First the author identifies the inadequacy of a legal provision regarding the situation(s) intended to be covered thereby. It is shown that the provision is not exhaustive in that regard. A solution is recommended for examination and possible adoption. In contrast the other provision examined is substantially adequate but its literary presentation 
is uncommonly complex. In a word it is unwieldy. It is argued that such presentation is likely to have adverse impact on comprehensiveness. No solution is suggested for the second situation; on the contrary a challenge is thrown to local legal draftsmen to provide a remedy. Having shown that comprehensiveness means more than adequacy, the author expresses the hope that legal draftsmen will turn out laws that are both adequate and wieldy.

\section{Economic Development in the Third World and Innovations in Industrial Structure in Indu- strialized Countries: the Example of West Germany and France}

\section{By Ulrich Hilpert}

Because of the increases of oil prices new energy technologies are encountering promising market conditions. The regions where these new technological concepts are suitable are mainly situated in the Third World; its climatic conditions, the dramatic increase of future energy needs and the social development to be faced in the near future will accentuate the need and expand the world market for solar technologies steadily. Industrialized countries are interested in participating in this new market and are setting up national solar industries. These innovations of the industrial structure are interwoven with the developments in the Third World. Which form they take depends on government policies and on the relations with the countries purchasing this technology.

The French neo-colonial policy within the Franc-Zone leads to a substitutive modernisation of French industry as the effects are limited to the traditional energy sources that are to be substituded; whereas the cooperation of West Germany with threshold countries leads to a dynamic substitution, the promotion of the processes for development in the buyer countries leading to a progressive increase of demand and to a sustained dynamism to expand the innovation of the industrial structure. 